\title{
Evaluation of Germplasm Genetic Variability, Heritability and Genetic Advance in Fenugreek (Trigonella foenum-graecum L.)
}

\author{
Som Prakash ${ }^{1}$, V. P. Pandey ${ }^{1}$, Deepak Kumar Gautam, \\ Amit Kumar Bhargava ${ }^{1}$ and Triloki Nath $^{2} *$ \\ ${ }^{1}$ Department of Vegetable Science, College of Horticulture and Forestry, \\ Narendra Deva University of Agriculture and Technology, Kumarganj, \\ Faizabad (Ayodhya) 224229, Uttar Pradesh, India \\ ${ }^{2}$ Shri Rampal Mahavidyalaya Baheriya Sandila, Hardoi, Uttar Pradesh, India \\ *Corresponding author
}

\section{A B S T R A C T}

The present experiment was carried out "Evaluation of germplasm genetic variability, heritability and genetic advance in fenugreek (Trigonella foenum-graecum L.)"during Rabi season of the year 2014-2015 at Main Experiment Station of Department of Vegetable

\section{Keywords}

Fenugreek, Genetic variability,

Heritability and genetic advance

\section{Article Info}

Accepted:

04 March 2020

Available Online:

10 April 2020 Science (Vegetable Research Farm) at Narendra Deva University of Agriculture and Technology, Narendra Nagar (Kumarganj), Faizabad (Ayodhya) Uttar Pradesh, India. The characters studied and observations on various characters maximum recorded revealed that the characters studied were days to $50 \%$ flowering (89.42), days to maturity (145.21), plant height $(80.65 \mathrm{~cm})$, branches per plant (5.14), pods per plant (45.55), length of pods $(16.60 \mathrm{~cm})$, seeds per pod (19.66), 1000 seed weight $(10.78 \mathrm{~g})$, seed yield per plant (5.96 $\mathrm{g}$ ) and seed yield (19.19 q/ha).The study revealed genetic variation for all studied traits in fenugreek. Analyses of variance for the design of experiment of fenugreek showed that block were highly significant for all the characters. The PCV was higher in magnitude than GCV. The maximum phenotypic and genotypic variances were observed for number of branches per plant $(19.56 \%, 19.49 \%)$ followed by seed yield q/ha $(17.20 \%, 17.16 \%)$ respectively. Heritability estimates were high for seed yield (99.57\%) followed by branches per plant $(99.30 \%)$ and Very high genetic advance in per cent of mean showed branches per plant $(51.26 \%)$ followed by seed yield $(45.19 \%)$.

\section{Introduction}

Fenugreek, commonly called Greekhayes or "Methi", is the dried ripe fruit of the pulse Trigonella foenum-graecum Linn. $(2 \mathrm{n}=16)$ (Fryer, 1930), belongs to family Fabaceae. It has been originated in Egypt. Fenugreek can be grown in the tropics and in temperate regions. It is grown from sea level up to an altitude of $2000 \mathrm{~m}$. Botanically, the genus Trigonella comprises 50 species, mostly of Mediterranean and Oriental origin. There are 
two species of the genus Trigonella, which are of economic importance, viz., Trigonella foenum-graecum or the commonly called "methi" and Trigonella corniculata or the "kasthuri methi." Fenugreek is an annual herb, 30 to $90 \mathrm{~cm}$ tall and has light green leaves which are pinnately trifoliate. The flowers are papillonaceaus and white or yellow in colour and produces stander, beaked pods of approximately $10-15 \mathrm{~cm}$ long and each pod contains 10-20 small hard yellowish brown seed possessing smooth and oblong, about $3 \mathrm{~mm}$ long, each grooved across one corner, giving them a hooked appearance.

India has been known as land of spices since very early period of recorded history. The history of Indian spices is known to be dates back to the beginning of human civilization. Moreover, references are also available with regard to Indian spices and their use in Vedas (6000 B.C.) by Manu (4000 B.C.). According to the Bureau of Indian Standard, 63 kinds of spices are grown in the country. However, in India it is mainly grown in Rajasthan, Madhya Pradesh, U.P., Gujarat and Punjab. Rajasthan claims the monopoly in production accounting for about $80 \%$ of fenugreek produce in the country. The seeds are used as spices and condiment to improve the flavour and nutritive value of food. Being due to its mucilaginous, demulcent diuretic, carminative, astringent, emollient and aphrodisiac properties of seeds are also used in preparation of several ayurvedic medicines. Besides young green tender plant and leaves are also used as nutritionally rich the vegetable. Fenugreek which form the actual spice is rich source of vitamin $A, C$ and $B_{2}$ (Aykroyd, 1963), protein (Rao and Sharma 1987). Seed contains diosgenin which is used in the preparation of contraceptive pills. Fenugreek is grown during Rabi or winter season as a leafy vegetable. Seed or leaf spices for human consumption (Som and Maity, 1986) fodder for the animal (Jatasra and Lodhi, 1980) and green manure to enrich the soil fertility through nitrogen fixation, i.e. above $283 \mathrm{~kg}$ N/ha (Gill and Singh, 1988 and Kohli, 1983).

\section{Materials and Methods}

The experimental material consisted of 122 genotypes Narendra Methi (NDM-1) to Narendra Methi (NDM-120) including two check varieties Pusa Early Bunching (PEB) IARI, New Delhi and Hisar Sonali (C.C.S.H.A.U., Hisar, Haryana) was carried out during Rabi season of the year 2014-15 at Main Experiment Station of Department of Vegetable Science (Vegetable Research Farm) at Narendra Deva University of Agriculture and Technology, Narendra Nagar (Kumarganj), Faizabad (Ayodhya) Uttar Pradesh, India. Geographically the experimental site falls under humid subtropical climate and it is located at $26^{\circ} 47^{\prime}$ $\mathrm{N}$ latitude and $82^{\circ} 12^{\prime} \mathrm{E}$ longitudes at an elevation of altitude of 113 meter above the mean sea level. It falls in north east gangetic alluvial plains of eastern U.P. Faizabad region. The experiment was laid out in Augmented Block Design with three replications individual plot size $(2 \mathrm{~m} \times 1.2$ $\mathrm{m})$. The distance maintained between row to row and plant to plant $(30 \mathrm{~cm} \times 10 \mathrm{~cm})$. The field had sandy loam soil, low in organic carbon and slightly alkaline in nature $(\mathrm{pH}$ 8.0). All recommended agronomic practices for the region were adopted to raise healthy crops. Five plants were selected randomly from each plot to record. For the data observation 10 characters were considered viz., days to $50 \%$ flowering, days to maturity, plant height $(\mathrm{cm})$, branches per plant, pods per plant, length of pod $(\mathrm{cm})$, seeds per pod, 1000-seed weight $(\mathrm{g})$, seed yield per plant $(\mathrm{g})$ and seed yield (q/ha).

\section{Statistical analysis}

The statistical analysis was done by using the techniques of analysis of "Augmented Block 
Design". These designs were developed by Federer (1956).

\section{Estimation of coefficient of variation (PCV \& GCV)}

Variability for different characters was estimated as suggested by Burton and de Vane (1953). The formulae used in the estimation of coefficients of variability at genotypic (GCV), and phenotypic (PCV) levels are as follows:

$$
\begin{gathered}
\text { GCV } \%=\frac{\text { Genotypic standard deviation }}{\text { Mean }} \times 100 \\
\text { PCV\% }=\frac{\text { Phenotypic standard deviation }}{\text { Mean }} \times 100
\end{gathered}
$$

\section{Estimation of heritability}

Heritability in broad sense $\left(\mathrm{h}^{2}\right)$ was calculated by the following formula suggested by Hanson et al., (1956).

$\mathrm{h}_{(\mathrm{bs})}^{2}=\frac{\sigma 2 g}{\sigma 2 g+\sigma 2 e}$ or $\frac{\sigma 2 g}{\sigma 2 p} \cdot 100$

Where,

$\mathrm{h}^{2}(\mathrm{bs})=$ Heritability in broad sense

$\sigma^{2} \mathrm{~g}=$ Genotypic variance

$\sigma^{2} \mathrm{p}=$ phenotypic variance

\section{Estimation of genetic advance (GA)}

Expected genetic advance was estimated by the method suggested by Johnson et al., (1955).

$\mathrm{GA}=\frac{\sigma^{2} \mathrm{~g}}{\sigma \mathrm{p}} \times \mathrm{K}$

Where,

$\mathrm{K}=$ Selection differential at $5 \%$ selection intensity i.e. 2.06

\section{Estimation of genetic advance in per cent} of mean (GA\%)

Genetic advance in percent of mean was calculated by the methods given by Johnson et al., (1955).

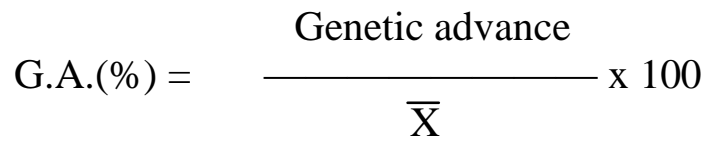

Where,

$\overline{\mathrm{X}}=$ Grand mean of the character

\section{Results and Discussion}

The analysis of variance for One hundred twenty two genotypes for all the ten characters were carried out in Augmented Block Design and the results of analysis of variance are presented in Table no 1. In Analysis of variance, the variances due to blocks were highly significant for all the characters, except days to maturity. The variance due to checks were non-significant for plant height, branches per plant, seeds per pod, 1000-seed weight while remaining characters were highly significant.

The data presented in table no. 2 shows that significant response in the highest and lowest range was recorded for days to $50 \%$ flowering (89.42 - 77.42) followed by days to maturity (145.21 - 130.00), plant height (80.65 $60.84)$, branches per plant (5.14 - 2.34), length of pod (16.60 - 9.87), pods per plant (45.55 - 24.92), seeds per pod (19.66 - 11.52), 1000 -seed weight $(10.78-7.12)$, seed yield 
per plant (5.96 - 3.10) and seed yield (19.19 9.95) respectively.

The phenotypic coefficient of variation (PCV)was estimated for one hundred twenty two genotypes for ten characters. The number of branches per plant (19.56\%) showed highest phenotypic coefficient of variation followed by seed yield q/ha (17.20\%) seed yield per plant $(16.80 \%)$ and pods per plant $(15.68 \%)$ whereas, lowest was recorded for plant height (3.94\%) followed by days to $50 \%$ flowering (3.18\%) and days to maturity $(1.32 \%)$.The existence of high variability for number of branches per plant and pods per plant in fenugreek was in conformity with the findings of earlier workers by Raghuvanshi and Singh (1982); Baswana et al., (1984); Kohli et al., (1988); Venkata Reddy et al., (1991); Mehta et al., (1992); Lowanshi et al., (1996).

The genotypic coefficient of variation (GCV) was estimated for one hundred twenty two genotypes for ten characters. The number of branches per plant (19.49\%) showed highest genotypic coefficient of variation followed by seed yield q/ha (17.16\%), seed yield per plant (16.67\%), and pods per plant $(15.58 \%)$,whereas, low was recorded for plant height $(3.73 \%)$ followed by days to $50 \%$ flowering $(2.82 \%)$. On the other hand days to maturity $(-1.33 \%)$ exhibited negative genotypic coefficient of variation. similar to the present findings of Kole and Mishra (2006); Sarada et al., (2008); Singh and Pramila (2009); Naik et al., (2009); Prajapati et al., (2010); Naik et al., (2011); Singh et al., (2014).

The high value of broad sense heritability was recorded for seed yield $(99.57 \%)$ followed by branches per plant $(99.30 \%)$, pods per plant (98.79\%), seed yield per plant $(98.50 \%)$, seeds per pod $(97.77 \%), 1000$-seed weight (96.50\%), length of pod $(94.75 \%)$, plant height $(89.61 \%)$ and low value of broad sense heritability was recorded for days to $50 \%$ flowering $(51.36 \%)$. days to maturity ($100.5 \%$ ) exhibited negative heritability. These results are in confirmed with Hanson et al., (1956).

Table.1 Analysis of variance for 10 characters in fenugreek

\begin{tabular}{|c|c|c|c|c|}
\hline \multirow{3}{*}{$\begin{array}{c}\text { S. } \\
\text { No. }\end{array}$} & \multirow[t]{2}{*}{ Characters } & \multicolumn{3}{|c|}{ Source of variation } \\
\hline & & Block & Check & Error \\
\hline & d. f. & 11 & 1 & 11 \\
\hline 1. & Days to $50 \%$ flowering & 3.72 & $112.67 * *$ & 3.31 \\
\hline 2. & Days to maturity & 6.22 & $330.05 * *$ & 6.78 \\
\hline 3. & Plant height $(\mathbf{c m})$ & 5.79 & 11.74 & 0.89 \\
\hline 4. & Number of branches per plant & $0.29 * *$ & $2.16 * *$ & 0.003 \\
\hline 5. & Number of pods per plant & $117.76^{* *}$ & 3.84 & 0.33 \\
\hline 6. & Length of pod (cm) & $0.007 * *$ & $3.84 * *$ & 0.067 \\
\hline 7. & Number of seed per pod & $11.71 * *$ & $1.52 * *$ & 0.055 \\
\hline 8. & 1000-seed weight $(\mathrm{g})$ & $1.76 * *$ & $17.38 * *$ & 0.017 \\
\hline 9. & Seed yield per plant (g) & $2.31 * *$ & $1.52 * *$ & 0.008 \\
\hline 10. & Yield (q/ha) & $26.42 * *$ & $17.31 * *$ & 0.025 \\
\hline
\end{tabular}


Table. 2 Range, general mean, phenotypic and genotypic coefficient of variation, heritability $\mathrm{h}^{2}$ (bs), genetic advance in per cent of mean and coefficients variation for 10 characters in fenugreek germplasm

\begin{tabular}{|c|c|c|c|c|c|c|}
\hline \multirow[t]{2}{*}{ Character } & \multirow{2}{*}{$\begin{array}{c}\text { Range } \\
\text { Lowest - highest }\end{array}$} & \multirow{2}{*}{$\begin{array}{l}\text { Grand } \\
\text { mean } \\
\text { (X) }\end{array}$} & \multicolumn{2}{|c|}{ Variance } & \multirow{2}{*}{$\begin{array}{l}\text { Heritability } \\
\mathbf{H}_{2(\mathrm{bs})}(\%)\end{array}$} & \multirow{2}{*}{$\begin{array}{c}\text { Genetic } \\
\text { advance in per } \\
\text { cent of mean } \\
\text { (GA \%) }\end{array}$} \\
\hline & & & $\begin{array}{l}\text { PCV } \\
(\%)\end{array}$ & $\begin{array}{l}\text { GCV } \\
(\%)\end{array}$ & & \\
\hline Days to $50 \%$ flowering & $77.42-89.42$ & 82.19 & 3.18 & 2.28 & 51.36 & 4.30 \\
\hline Days to maturity & $130.00-145.21$ & 139.22 & 1.32 & -1.33 & -100.5 & -3.50 \\
\hline Plant height (cm) & $60.84-80.65$ & 74.14 & 3.94 & 3.73 & 89.61 & 9.30 \\
\hline Branches per plant & $2.34-5.14$ & 3.42 & 19.56 & 19.49 & 99.30 & 51.26 \\
\hline Pods per plant & $24.92-45.55$ & 32.14 & 15.68 & 15.58 & 98.79 & 40.85 \\
\hline Length of pod (cm) & $9.87-16.60$ & 13.02 & 8.67 & 8.44 & 94.75 & 21.67 \\
\hline Seed per pod & $11.52-19.66$ & 15.73 & 9.89 & 9.78 & 97.77 & 25.52 \\
\hline 1000 seed weight (g) & $7.12-10.78$ & 9.20 & 7.62 & 7.48 & 96.50 & 19.38 \\
\hline Seed yield per plant (g) & $3.10-5.96$ & 4.20 & 16.80 & 16.67 & 98.50 & 43.66 \\
\hline Seed yield (q/ha) & $9.95-19.19$ & 13.77 & 17.20 & 17.16 & 99.57 & 45.19 \\
\hline
\end{tabular}

The genetic advance in per cent of mean ranged from branches per plant $(51.26 \%)$ to days to maturity $(-3.50 \%)$.the highest genetic advance was recorded for branches per plant $(51.26 \%)$ followed by seed yield $(45.19 \%)$, seed yield per plant (43.66\%), pods per plant (40.85\%), seeds per pod (25.52\%), length of pod $(21.67 \%), 1000$-seed weight $(19.38 \%)$ whereas, lowest value of plant height $(9.30 \%)$ followed by days to $50 \%$ flowering $(4.30 \%)$, days to maturity(-3.50\%) exhibited negative genetic advance in percent of mean. This result corroborates the findings of Johnson et al., (1955).

\section{References}

Aykroyd, W.R. (1963). The nutritive value of Indian foods and planning for satisfactory diets. ICMR Special Report, Series No. 42.
Burton, G.W. and de Vane, E.W. (1953). Estimating heritability in tall fescue (Festuca arundinacea) from replicated clonal material. Agron. J., 45: 478-481.

Baswana, K.S., Pandita, M.L. and Malik, Y.S. (1984).Variability studies in fenugreek. Haryana J. Hort. Sci., 13 (1-2):78-81.

Federer, W.T. (1956). Augmented design 'Hawaiin planters' records 55:191-208.

Gill, S.S. and Singh, H. (1988).Effect of planting date and leaf cutting on the seed yield of methi (Trigonella foenumgraecum L.). J. Res. Punjab Agric. Univ. Ludhiana, 25: 206-209.

Hanson, C. H., Robinson, H.F. and Comstock, R.E. (1956).Biometrical studies of yield in segregating population of Korean Lespedeza Agron. J., 48: 268-271.

Johnson, H.W., Robinson, H.F. and Comstock R.K. (1955).Estimates of genetic and 
environmental variability in soybean. Agron. J., 47:314-318.

Johnson, H.W., Robinson, H.F. and Comstock R.K. (1955). Genotypic and phenotypic correlation in soybean and their implication in selection. Agron. J., 47: 477-488.

Jatasra, D.S. and Lodhi, G.P. (1980).Suitable fodder for grain crop for late sowing. Haryana Fmg., 9(12): 7.

Kohli, U.K. (1983). Agro-techniques for leaf vegetables. In: Advances in Horticulture (K.L. Chadha \& G. Kalloeds.) pp. 524528. Malhotra Publishing House, New Delhi.

Kohli, U.K., Sharma, O.P. and Singh, J. (1988). Genetic variability, correlation and path analysis in fenugreek. Indian J. Hort., 45: 119-125.

Kole, P.C. and Mishra, A.K. (2006). Pattern of variability and association among quantitative characters in fenugreek. Indian Agril., 50 (3/4): 93-96.

Lowanshi, R.K., Shukla, R.S., Dubey, R.K., Choubey, P.C. and Singh, M. (1996). Source and sink parameters in fenugreek (Trigonella foenum-graecum L.). J. Soils Sci. Crops, 6 (1): 10-14.

Mehta, K.G., Patel, R.H. and Kachhadia, B.T. (1992).Genetic variability and path analysis in fenugreek. Indian Cocoa, Arecanut, Spices J., 15 (4): 114-117.

Naik, A., Akhtar, S. and Pandey, V.P. (2011). Genetic variability, heritability and genetic advance in fenugreek. Environment and Ecology, 29:4A, 2050-2051.

Naik, A., Bhunia, P. and Pandey, V.P. (2009). Effect of genotypes on growth yield attributes and yield of fenugreek. Indian
Agril., 53(3/4); 111-113.

Prajapati, D.B., Ravindrababu, Y. and Prajapati, B.H. (2010). Genetic variability and character association in fenugreek. $J$. spice and aromatic crops, 19(1/2):61-64.

Rao, P.U. and Sharma, R.D. (1987).An evaluation of protein quality of fenugreek seed (Trigonella foenum graecum L.) and their supplementary effect. Food Chemistry, 24(1):1-9.

Raghuvanshi, S.S. and Singh, R.R. (1982).Genetic variability in fenugreek Indian J. Hort., 39: 134-138.

Som, M.G. and Maity, T.K. (1986). Fenugreek In: Vegetable crops in India (T.K. Bose and M.G. Som, eds.) NayaPrakash. Calcutta, India, pp 680-686.

Sarada, C., Giridhar, K. and Rao, N.H. (2008). Studies on genetic variability, heritability and genetic advance in fenugreek. $J$. spices and Aromatic crops, 17 (2): 163-166.

Singh, S.P. and Pramila (2009).Genetic variability, heritability and genetic advance for quantitative characters in fenugreek. Asian J. Hort., 4(1):167-169.

Som, M.G. and Maity T.K. (1986). Fenugreek in: vegetable crops in India. Naya Prakash. Calcutta India, pp680-686.

Singh, M. K. (2014). Genetic variability, heritability, genetic advance and correlation coefficient analysis in fenugreek (Trigonella foenum-graecum L.). Hort Flora Research Spectrum, 3(2):178-180.

Venkata, Reddy, P. and Narisi, Reddy, A. (1991). Genetic variability in fenugreek. Indian Cocoa, Arecanut Spices. J. 15(2): 49-52.

\section{How to cite this article:}

Som Prakash, V. P. Pandey, Deepak Kumar Gautam, Amit Kumar Bhargava and Triloki Nath. 2020. Evaluation of Germplasm Genetic Variability, Heritability and Genetic Advance in Fenugreek (Trigonella foenum-graecum L.). Int.J.Curr.Microbiol.App.Sci. 9(04): 303-308. doi: https://doi.org/10.20546/ijcmas.2020.904.036 